\title{
Faktor Risiko Kejadian Anemia Ibu Hamil di Rumah Sakit Umum Daerah dr. Zainoel Abidin Provinsi Aceh Tahun 2013-2015
}

\author{
Risk Factors for Incident of Maternal Anemia who Carry Out Checkup in \\ General Hospital of dr. Zainoel Abidin Aceh Province in 2013-2015 \\ Faradilla Safitri $^{*}$, Herman Sudiman ${ }^{2}$ \\ ${ }^{1}$ Program Studi D-IV Bidan Pendidik, Fakultas Ilmu Kesehatan, Universitas Ubudiyah Indonesia, Banda Aceh, Indonesia \\ ${ }^{2}$ Fakultas Kesehatan Masyarakat, Universitas Respati Indonesia, Jln. Bambu Apus 1, Jakarta Timur, Indonesia ${ }^{2}$ \\ *Korespondensi Penulis: faradilla@uui.ac.id
}

\begin{abstract}
Abstrak
Anemia merupakan kelainan darah yang umum terjadi ketika kadar sel darah merah dalam tubuh menjadi rendah. Tujuan penelitian ini adalah untuk menganalisis hubungan umur, paritas, pendidikan, pekerjaan, umur kehamilan, asal rujukan, dan layanan kesehatan dengan kejadian anemia pada ibu hamil. Jenis penelitian bersifat analitik menggunakan desain kasus kontrol. Perbandingan jumlah sampel kasus dan kontrol 1:2, yaitu sampel kasus 173 dan sampel kontrol 346. Total sampel sebanyak $519 \mathrm{ibu}$ hamil. Pengumpulan data menggunakan data sekunder yakni data diambil dari buku register tahun 2013-2015. Hasil penelitian analisis bivariat variabel umur $<20$ tahun dengan kejadian anemia $(\mathrm{OR}=9,549)$, paritas $(\mathrm{OR}=1,955)$, umur kehamilan $(\mathrm{OR}=1,608)$, pendidikan $(\mathrm{OR}=2,338)$, pekerjaan $(\mathrm{OR}=2,167)$, asal rujukan $(\mathrm{OR}=0,418)$ dan layanan kesehatan $(\mathrm{OR}=1,361)$. Kesimpulan : ada hubungan umur, paritas, umur kehamilan, pendidikan, pekerjaan dan asal rujukan dengan kejadian anemia ibu hamil, sedangkan layanan kesehatan tidak berhubungan dengan kejadian anemia ibu hamil dengan $\mathrm{p}$ value $=0,299$.
\end{abstract}

Kata kunci : Anemia, umur, pendidikan, umur kehamilan, paritas

\begin{abstract}
Anemia is a common blood disorder that occurs when levels of red blood cells in the body becomes too low. The purpose of this study is to analyze the relationship between age, parity, education, occupation, gestational age, origin of a referral, and health services. This type of research is analytic survey using case control design. The comparison of the number of cases samples and controls 1:2, the sample 173 cases and 346 control samples. Total sample of this research is 519 pregnant women. Collecting data using secondary data that the data retrieved from the register book years 2013-2015. The results of bivariate analysis between age <20 years with anemia inicident $(O R=9.549)$, parity $(O R=1.955)$, gestational age $(O R=$ $1.608)$, education $(O R=2.338)$, occupation $(O R=2.167)$, the origin of a referral $(O R=$ $0.418)$ and health care $(O R=1.361)$. In conclusion, there is correlation between age, parity, gestational age, education, occupation and origin of a referral to the incidence of anemia in
\end{abstract}


pregnant women, while health services are not associated with anemia among pregnant women with $p$ value $=0.299$.

Keywords: Anemia, age, education, gestational age, parity

\section{PENDAHULUAN}

Anemia merupakan salah satu kelainan darah yang umum terjadi ketika kadar sel darah merah (eritrosit) dalam tubuh menjadi rendah. Hal ini menyebabkan masalah kesehatan karena sel darah merah mengandung hemoglobin, yang membawa oksigen ke jaringan tubuh ${ }^{[1]}$. Anemia adalah kondisi dengan kadar hemoglobin di bawah 11 gr/dl pada ibu hamil trimester I dan III atau kadar <10,5 gr/dl pada trimester II. Anemia pada kehamilan dapat disebabkan karena kekurangan zat besi dan merupakan jenis anemia yang pengobatannya relatif mudah bahkan murah ${ }^{[2]}$.

Berdasarkan data Riskesdas 2013, terdapat 37,1\% ibu hamil anemia, yaitu ibu hamil dengan kadar Hb kurang dari 11,0 gr/dl. Data Profil Kesehatan Provinsi Aceh Tahun 2013, angka kejadian anemia ibu hamil yang melakukan pemeriksaan sebanyak 1.301 orang. Sedangkan di Kota Banda Aceh, ibu hamil yang mengalami anemia sedang ( -99 gr/dl) sebanyak 109 orang $(4,1 \%)$ dan yang mengalami anemia berat $(<7 \mathrm{gr} / \mathrm{dl})$ sebanyak 2 orang $(0,07 \%)^{[3]}$.

Rumah Sakit Umum Daerah dr. Zainoel Abidin adalah rumah sakit negeri Tipe A. Rumah sakit ini mampu memberikan pelayanan kedokteran spesialis dan subspesialis luas oleh pemerintah ditetapkan sebagai rujukan tertinggi atau disebut pula sebagai rumah sakit pusat. Berdasakan data yang didapatkan dari rekam medik di Rumah Sakit Umum Daerah dr. Zainoel Abidin, jumlah ibu hamil yang berkunjung pada tahun 2013 sebanyak 1350 orang dan $41(3,03 \%)$ ibu hamil di antaranya mengalami anemia. Pada tahun 2014 jumlah ibu hamil sebanyak 2580 orang, 71 (2,9\%) ibu hamil mengalami anemia defisiensi besi. Pada tahun 2015 jumlah ibu hamil mulai dari bulan Januari sampai Oktober 2015, sebanyak 1768 orang dan 61 orang $(3,4 \%)$ di antaranya mengalami anemia ${ }^{[4]}$.

Berdasarkan data WHO tahun 2008, prevalensi anemia ibu hamil sebesar 47,40\%, di Amerika jumlah ibu hamil yang mengalami anemia pada trimerter I sebanyak $8 \%$, trimester II sebanyak $12 \%$ dan trimester III sebanyak $29 \%{ }^{[5]}$. Data di Riskesdas dengan jumlah ibu hamil mengalami anemia sebanyak 37,1\%, hal ini sangat berbeda jauh dengan angka kejadian anemia pada ibu hamil di Rumah Sakit Umum Daerah dr.Zainoel Abidin dengan jumlah 
persentase sangat rendah yaitu 2,9\% sampai 3,4\% saja. Dengan demikian peneliti ingin mengetahui mengapa angka kejadian anemia pada ibu hamil ini sangat rendah, dari manakah asal rujukan ibu hamil tersebut, bagaimanakah layanan kesehatan tempat asal rujukan ibu hamil yang dilihat dari rasio bidan dengan jumlah ibu hamil, serta apakah faktor risiko usia ibu, paritas, umur kehamilan, pendidikan ibu dan pekerjaan ibu berhubungan dengan kejadian anemia ibu hamil yang melakukan pemeriksaan di Rumah Sakit Umum Daerah dr. Zainoel Abidin Tahun 2013-2015.

\section{METODE PENELITIAN}

Jenis penelitian ini bersifat analitik menggunakan desain kasus kontrol. Populasi kasus dalam penelitian ini adalah seluruh ibu hamil anemia yang melakukan kunjungan dan tercatat di buku register pada bulan Januari 2014 sampai Oktober 2015 sebanyak 173 orang, dan populasi kontrol sebanyak 5698 orang. Peneliti membuat perbandingan antara jumlah sampel kelompok kasus dan kontrol $1: 2$ sehingga jumlah sampel dalam penelitian ini adalah 173 kasus dan sampel control 346, jumlah sampel keseluruhan 519 orang. Cara pengambilan sampel dilakukan secara acak sistematis. Instrumen penelitian menggunakan checklist. Analisis data menggunakan analisis data univariat, bivariat dan multivariat.

\section{HASIL DAN PEMBAHASAN}

Tabel 1. Hubungan Umur dengan Kejadian Anemia pada Ibu Hamil di Rumah Sakit Umum Daerah dr.Zainoel Abidin Provinsi Aceh Tahun 2013-2015

\begin{tabular}{|c|c|c|c|c|c|c|c|}
\hline \multirow[t]{3}{*}{ No } & \multirow[t]{3}{*}{ Umur } & \multicolumn{4}{|c|}{ Kejadian Anemia } & \multirow{3}{*}{$\begin{array}{c}P \\
\text { Value }\end{array}$} & \multirow[t]{3}{*}{ OR } \\
\hline & & \multicolumn{2}{|c|}{ Anemia } & \multicolumn{2}{|c|}{ Tidak Anemia } & & \\
\hline & & $\mathbf{n}$ & $\%$ & $\mathbf{n}$ & $\%$ & & \\
\hline \multirow[t]{3}{*}{1} & Berisiko & & & & & & \\
\hline & $-\quad<20$ Tahun & 15 & 8,7 & 4 & 1,2 & 0,001 & 9,549 \\
\hline & - $>35$ Tahun & 61 & 35,3 & 95 & 27,4 & 0,020 & 1,634 \\
\hline 2 & $\begin{array}{l}\text { Tidak Berisiko } \\
\text { (20-35 Tahun) }\end{array}$ & 97 & 56,0 & 247 & 71,4 & & \\
\hline \multicolumn{2}{|c|}{ Jumlah } & 173 & 100 & 346 & 100 & & \\
\hline
\end{tabular}

Berdasarkan Tabel 1 terlihat bahwa dari kelompok kasus ibu hamil dengan umur berisiko (>35 tahun) sebanyak 35,3\%, sedangkan dari kelompok kontrol umur ibu yang berisiko (>35 tahun) sebanyak 27,4\%. Hasil uji statistik dengan pemilahan umur kategori 
berisiko yaitu umur $<20$ tahun didapat $p$ value $=0,001$ dan $\mathrm{OR}=9,549$. Dan umur $>35$ tahun didapat $\mathrm{p}$ value $=0,020$ dan $\mathrm{OR}=1.635$. Artinya, ibu hamil yang berumur $<20$ tahun memiliki risiko 9,549 kali lebih besar mengalami anemia dibandingkan umur $>35$ tahun.

Tabel 2. Hubungan paritas dengan kejadian anemia ibu hamil di Rumah Sakit Umum Daerah dr.Zainoel Abidin Provinsi Aceh Tahun 2013-2015

\begin{tabular}{|c|c|c|c|c|c|c|c|}
\hline \multirow{3}{*}{ No } & \multirow{3}{*}{ Paritas } & \multicolumn{4}{|c|}{ Kejadian Anemia } & \multirow{3}{*}{ p value } & \multirow{3}{*}{$\mathbf{O R}$} \\
\hline & & \multicolumn{2}{|c|}{ Anemia } & \multicolumn{2}{|c|}{ Tidak Anemia } & & \\
\hline & & $\mathbf{n}$ & $\%$ & $\mathbf{n}$ & $\%$ & & \\
\hline 1 & Berisiko $(>2)$ & 76 & 43,9 & 99 & 28,6 & & \\
\hline 2 & Tidak Berisiko $(\leq 2)$ & 97 & 56,1 & 247 & 71,7 & 0,001 & 1,955 \\
\hline \multicolumn{2}{|c|}{ Jumlah } & 173 & 100 & 346 & 100 & & \\
\hline
\end{tabular}

Berdasarkan Tabel 2 terlihat bahwa dari dalam kelompok kasus ibu yang memiliki paritas >2 sebanyak 43,9 \%, sedangkan dari kelompok kontrol ibu yang memiliki paritas berisiko sebanyak 28,6\%. Hasil uji statistik diperoleh $p$ value $=0,001$, artinya ada hubungan yang signifikan antara paritas dengan kejadian anemia pada ibu hamil dengan nilai OR = 1,955, yaitu ibu yang memiliki paritas >2 mempunyai peluang 1,955 kali lebih besar mengalami anemia dibandingkan ibu dengan paritas tidak berisiko.

Tabel 3. Hubungan Umur Kehamilan dengan Kejadian Anemia Ibu Hamil di Rumah Sakit Umum Daerah dr. Zainoel Abidin Provinsi Aceh Tahun 2013-2015

\begin{tabular}{|c|c|c|c|c|c|c|c|}
\hline \multirow{3}{*}{ No } & \multirow{3}{*}{$\begin{array}{c}\text { Umur } \\
\text { kehamilan }\end{array}$} & \multicolumn{4}{|c|}{ Kejadian Anemia } & \multirow{3}{*}{$\begin{array}{c}p \\
\text { value }\end{array}$} & \multirow{3}{*}{ OR } \\
\hline & & \multicolumn{2}{|c|}{ Anemia } & \multicolumn{2}{|c|}{ Tidak Anemia } & & \\
\hline & & $\mathbf{n}$ & $\%$ & $\mathbf{n}$ & $\%$ & & \\
\hline 1 & Trimester II & 57 & 32,9 & 81 & 23,4 & & \\
\hline \multirow[t]{2}{*}{2} & Trimester III & 116 & 67,1 & 265 & 76,6 & 0,027 & 1,608 \\
\hline & Jumlah & 173 & 100 & 346 & 100 & & \\
\hline
\end{tabular}

Berdasarkan Tabel 3 terlihat bahwa dari kelompok kasus terdapat ibu hamil trimester II sebanyak 32,9\%, sedangkan dari 346 kelompok kontrol ibu hamil trimester II sebanyak $23,4 \%$. Hasil uji statistik diperoleh $p$ value $=0,027$, artinya ada hubungan yang signifikan antara umur kehamilan dengan kejadian anemia pada ibu hamil dengan nilai $\mathrm{OR}=1,608$, yaitu ibu hamil trimester II mempunyai peluang 1,608 kali lebih besar mengalami anemia dibandingkan ibu hamil trimester III. 
Tabel 4. Hubungan pendidikan dengan kejadian anemia ibu hamil di Rumah Sakit Umum Daerah dr.Zainoel Abidin Provinsi Aceh Tahun 2013-2015

\begin{tabular}{|c|c|c|c|c|c|c|c|}
\hline \multirow[t]{3}{*}{ No } & \multirow[t]{3}{*}{ Pendidikan } & \multicolumn{4}{|c|}{ Kejadian Anemia } & \multirow{3}{*}{$\begin{array}{c}p \\
\text { value }\end{array}$} & \multirow[t]{3}{*}{ OR } \\
\hline & & \multicolumn{2}{|c|}{ Anemia } & \multicolumn{2}{|c|}{ Tidak Anemia } & & \\
\hline & & $\mathbf{n}$ & $\%$ & n & $\%$ & & \\
\hline 1 & Rendah ( $\leq$ SMA) & 153 & 88,4 & 265 & 76,6 & & \\
\hline 2 & Tinggi (>SMA) & 20 & 11,6 & 81 & 23,4 & 0,002 & 2,338 \\
\hline \multicolumn{2}{|c|}{ Jumlah } & 173 & 100 & 346 & 100 & & \\
\hline
\end{tabular}

Berdasarkan Tabel 4 terlihat bahwa dari kelompok kasus terdapat yang berpendidikan rendah sebanyak 88,4\%, sedangkan dari 346 kelompok kontrol umur ibu yang berpendidikan rendah sebanyak 76,6\%. Hasil uji statistik diperoleh $p$ value $=0,002$, artinya ada hubungan yang signifikan antara pendidikan dengan kejadian anemia pada ibu hamil dengan nilai $\mathrm{OR}=$ 2,338, yaitu ibu yang berpendidikan rendah mempunyai peluang 2,338 kali lebih besar mengalami anemia dibandingkan dengan ibu hamil yang berpendidikan tinggi.

Tabel 5. Hubungan pekerjaan dengan kejadian anemia ibu hamil di Rumah Sakit Umum Daerah dr.Zainoel Abidin Provinsi Aceh Tahun 2013-2015

\begin{tabular}{|c|c|c|c|c|c|c|c|}
\hline \multirow{3}{*}{ No } & \multirow{3}{*}{ Pekerjaan } & \multicolumn{4}{|c|}{ Kejadian Anemia } & \multirow{3}{*}{$\underset{\text { value }}{p}$} & \multirow{3}{*}{ OR } \\
\hline & & \multicolumn{2}{|l|}{ Anemia } & \multicolumn{2}{|c|}{ Tidak Anemia } & & \\
\hline & & $\mathbf{n}$ & $\%$ & $\mathbf{n}$ & $\%$ & & \\
\hline 1 & Tidak Bekerja & 154 & 89,0 & 273 & 78,9 & & \\
\hline 2 & Bekerja & 19 & 11,0 & 73 & 21,1 & 0,006 & 2,167 \\
\hline \multicolumn{2}{|c|}{ Jumlah } & 173 & 100 & 346 & 100 & & \\
\hline
\end{tabular}

Berdasarkan Tabel 5 terlihat bahwa dari kelompok kasus terdapat ibu yang tidak bekerja sebanyak 89,0\%, sedangkan dari 346 kelompok kontrol umur ibu yang tidak bekerja sebanyak 78,9\%. Hasil uji statistik diperoleh $p$ value $=0,006$, artinya ada hubungan yang signifikan antara paritas dengan kejadian anemia pada ibu hamil dengan nilai $\mathrm{OR}=2,167$, yaitu ibu yang tidak bekerja mempunyai peluang 2,167 kali lebih besar mengalami anemia dibandingkan dengan ibu hamil yang bekerja. 
Tabel 6. Hubungan Asal Rujukan dengan Kejadian Anemia Ibu Hamil di Rumah Sakit Umum Daerah dr.Zainoel Abidin Provinsi Aceh Tahun 2013-2015

\begin{tabular}{|c|c|c|c|c|c|c|c|}
\hline \multirow{3}{*}{ No } & \multirow{3}{*}{ Asal Rujukan } & \multicolumn{4}{|c|}{ Kejadian Anemia } & \multirow{3}{*}{ p value } & \multirow{3}{*}{ OR } \\
\hline & & \multicolumn{2}{|c|}{ Anemia } & \multicolumn{2}{|c|}{ Tidak Anemia } & & \\
\hline & & $\mathbf{N}$ & $\%$ & $\mathbf{n}$ & $\%$ & & \\
\hline 1 & Puskesmas & 155 & 89,6 & 330 & 95,4 & & \\
\hline 2 & Rumah Sakit & 18 & 10,4 & 16 & 4,6 & 0,020 & 0,418 \\
\hline \multicolumn{2}{|c|}{ Jumlah } & 173 & 100 & 346 & 100 & & \\
\hline
\end{tabular}

Berdasarkan Tabel 6 terlihat bahwa dari kelompok kasus terdapat ibu hamil yang dirujukan dari puskesmas sebanyak 89,6\%, sedangkan dari 346 kelompok kontrol umur ibu hamil yang dirujuk dari puskesmas sebanyak 95,4\%. Hasil uji statistik diperoleh $p$ value $=$ $0,020(<0,05)$, artinya ada hubungan yang signifikan antara asal rujukan dengan kejadian anemia pada ibu hamil dengan nilai $\mathrm{OR}=0,418$, yaitu ibu yang dirujuk dari puskesmas mempunyai peluang 0,418 kali mengurangi risiko anemia dibandingkan dengan ibu hamil yang dirujuk dari rumah sakit.

Tabel 7. Hubungan layanan kesehatan dengan kejadian anemia ibu hamil di Rumah Sakit Umum Daerah dr.Zainoel Abidin Provinsi Aceh Tahun 2013-2015

\begin{tabular}{|c|c|c|c|c|c|c|c|}
\hline \multirow{3}{*}{ No } & \multirow{3}{*}{$\begin{array}{l}\text { Layanan } \\
\text { Kesehatan }\end{array}$} & \multicolumn{4}{|c|}{ Kejadian Anemia } & \multirow{3}{*}{$\begin{array}{c}p \\
\text { value }\end{array}$} & \multirow{3}{*}{ OR } \\
\hline & & \multicolumn{2}{|c|}{ Anemia } & \multicolumn{2}{|c|}{ Tidak Anemia } & & \\
\hline & & $\mathbf{n}$ & $\%$ & $\mathbf{n}$ & $\%$ & & \\
\hline 1 & Tidak Baik & 28 & 16,2 & 43 & 12,4 & & \\
\hline 2 & Baik & 145 & 83,8 & 303 & 87,6 & 0,299 & 1,361 \\
\hline \multicolumn{2}{|c|}{ Jumlah } & 173 & 100 & 346 & 100 & & \\
\hline
\end{tabular}

Berdasarkan Tabel 7 terlihat bahwa dari kelompok kasus terdapat asal rujukan yang memiliki layanan kesehatan tidak baik sebesar 16,2\%, sedangkan dari kelompok kontrol memiliki layanan kesehatan yang tidak baik sebesar 12,4\%. Hasil uji statistik diperoleh $p$ value $=0,299$, artinya tidak ada hubungan antara layanan kesehatan dengan kejadian anemia pada ibu hamil.

\section{Pembahasan}

1. Hubungan Umur dengan Kejadian Anemia Ibu Hamil

Hasil penelitian ini sejalan dengan hasil penelitian di klinik perawatan antenatal Wolayita Sodo Town, Southern Ethiopia, ada hubungan umur dengan kejadian anemia 
pada ibu hamil dengan nilai $\mathrm{OR}=9,89$. Desain penelitian ini menggunakan cross-sectional dengan jumlah sampel sebanyak 363 ibu hamil. Pengumpulan data dilakukan dengan cara wawancara $^{[6]}$. Hasil penelitian yang telah dilakukan di puskesmas Jetis kota Yogyakarta, ada hubungan yang bermakna antara umur kehamilan dengan kejadian anemia pada ibu hamil, dengan $p$ value $=0,000$ dan $\mathrm{OR}=4,54$, artinya ibu hamil trimester II memiliki peluang 4,54 kali lebih besar mengalami anemia dibandingkan ibu hamil trimester I dan III $^{[7]}$.

Pada umur ibu (<20 tahun dan $>35$ tahun) berisiko mengalami anemia selama kehamilan sehingga dianjurkan untuk wanita usia muda untuk memunda pernikahan usia dini dan pada wanita usia lanjut sebaiknya mencukupkan kehamilannya agar tidak terjadi komplikasi pada saat kehamilan dan persalinan salah satunya mengalami anemia. Namun apabila sudah hamil dalam usia berisiko ini, maka sebaiknya ibu-ibu rutin melakukan pemeriksaan kondisi ibu dan janin selama kehamilan.

\section{Hubungan Paritas dengan Kejadian Anemia Ibu Hamil}

Hasil penelitian ini sejalan dengan penelitian yang telah dilakukan di Trinidad dan Tobago, yang menyatakan bahwa paritas berhubungan langsung dengan prevalensi anemia kehamilan. Penelitian retrospektif dan cross-sectional. Catatan antenatal 2287 wanita hamil yang melakukan pemeriksaan di 40 pusat kesehatan masyarakat dari Januari 2000 sampai Desember $2005^{[8]}$. Hal serupa juga ditemukan pada hasil penelitian yang dilakukan di Puskesmas Tuhemberua Nias Utara, dengan hasil ada hubungan paritas dengan kejadian anemia pada ibu hamil dengan nilai $\mathrm{p}=0,005$ dan $\mathrm{RP}=1,756^{[14]}$. Sama halnya dengan hasil penelitian yang dilakukan di Puskesmas Paal Lima, terdapat hubungan antara paritas dengan kejadian anemia dengan nilai $\mathrm{p}=0,000$ dan $\mathrm{RP}=3,440^{[15]}$.

Terlalu banyak melahirkan dapat mengakibatkan terjadinya penyakit dalam kehamilan sampai melahirkan salah satunya adalah anemia. Semakin sering seorang wanita mengalami kehamilan dan melahirkan akan makin banyak kehilangan zat besi. Apabila persediaan zat besi di dalam tubuh sedikit, maka setiap kehamilan akan menguras persediaan zat besi tersebut dan dapat berdampak menjadi anemia. Pada ibu yang memiliki paritas (>2) berisiko mengalami anemia, hal ini dipicu juga oleh jarak kehamilan. Apabila ibu ingin memiliki anak lebih dari dari dua, sebaiknya perhatikan kebutuhan zat gizi selama kehamilan dan rutin melakukan pemeriksaan antenatal care. 


\section{Hubungan Umur Kehamilan dengan Kejadian Anemia}

Hasil penelitian ini sejalan dengan penelitian yang dilakukan di Trinidad dan Tobago menyatakan ada hubungan antara umur kehamilan dengan kejadian anemia kehamilan $^{[8]}$. Pada umur kehamilan trimester ke II volume plasma meningkat 45-65\% dan maksimum terjadi pada bulan ke sembilan dan meningkat sekitar 1000 ml. Peningkatan volume plasma menyebabkan terjadinya hidremia kehamilan atau hemodilusi yang menyebabkan terjadinya penurunan hematokrit (20-30\%), sehingga hemoglobin lebih rendah $^{[1]}$.

Selama kehamilan jumlah zat besi dibutuhkan jauh lebih besar dibandingkan dengan ibu yang tidak hamil. Zat besi yang tersedia di dalam tubuh ibu akan di transfer ke janin sesuai dengan umur kehamilan. Pada trimester pertama zat besi ini belum terlalu banyak di serap ke janin, namun pada trimester II dan III jumlah zat besi yang dibutuhkan oleh tubuh meningkat. Pada ibu hamil dalam masa trimester II berisiko mengalami anemia, oleh karena itu selama kehamilan sebaiknya ibu mengonsumsi makanan dengan zat gizi baik serta mengonsumsi suplemen zat besi (tablet Fe) selama kehamilan secara rutin dan tetap mengontrol kondisi kesehatan ibu dan janin dengan melakukan pemeriksaan antenatal care.

4. Hubungan Pendidikan dengan Kejadian Anemia

Hasil penelitian ini sejalan dengan penelitian yang dilakukan di Sokoto North Western Nigeria, dengan hasil ada hubungan yang signifikan antara pendidikan dengan kejadian anemia pada ibu hamil dengan $p$ value $=0,034^{[9]}$. Hasil penelitian yang dilakukan pada ibu hamil di Makkah Arab Saudi tahun 2012, yang menyatakan bahwa ibu hamil yang berpendidikan rendah memiliki risiko 18,821 kali lebih besar mengalami anemia dibandingkan dengan ibu yang berpendidikan tinggi ${ }^{[10]}$.

Pendidikan yang dijalani seseorang memiliki pengaruh pada peningkatan kemampuan berpikir, artinya seseorang yang berpendidikan lebih tinggi akan dapat mengambil keputusan yang lebih rasional, mudah menerima perubahan, mudah menerima informasi sehingga pengetahuan tentang anemia dan faktor penyebabnya dapat dihindari, terutama pengetahuan tentang kebutuhan zat besi selama kehamilan. Ibu yang berpendidikan rendah berisiko mengalami anemia, namun hal ini dapat dicegah dengan cara ibu hamil sebaiknya mendapatkan informasi baik itu dari petugas kesehatan, media 
elektronik dan media cetak, tentang faktor apa saja yang dapat memicu terjadinya anemia selama kehamilan.

\section{Hubungan Pekerjaan dengan Kejadian Anemia}

Salah satu faktor tidak langsung yang mempengaruhi terjadinya anemia pada ibu hamil adalah status pekerjaan, hal ini biasanya berhubungan erat dengan pendapatan seseorang atau keluarga. Ibu hamil yang tidak bekerja kemungkinan akan menderita anemia lebih besar dibandingkan dengan ibu hamil yang bekerja. Pada ibu yang bekerja sosial ekonominya baik sehingga dapat menyediakan makanan terutama yang mengandung sumber zat besi dalam jumlah yang cukup ${ }^{[13]}$.

Hasil penelitian ini sejalan dengan hasil penelitian yang dilakukan Provinsi Lampung yang menyatakan bahwa ada hubungan antara pekerjaan dengan kejadian anemia dengan $p$ value $0,04^{[12]}$. Namun hasil penelitian ini berbeda dengan penelitian yang dilakukan di wilayah kerja puskesmas Alalak Tengah yaitu tidak ada hubungan antara pekerjaan dengan kejadian anemia pada ibu hamil dengan $p$ value 0,598 . Hal ini dikarenakan terdapat perbedaan jumlah sampel penelitian yang hanya 120 orang di satu kecamatan saja dan tanpa ada pembanding kasus dan kontrol ${ }^{[11]}$.

Ibu hamil yang melakukan pemeriksaan di rumah sakit umum Daerah dr.Zainoel Abidin sebagian besarnya tidak bekerja, hal ini dapat disebabkan oleh ibu yang tidak bekerja memiliki status ekonomi yang kurang baik sehingga melakukan pemeriksaan di rumah sakit negeri yang tidak memerlukan biaya untuk pemeriksaannya. Sedangkan ibu hamil yang bekerja banyak yang melakukan pemeriksaan langsung ketempat praktik dokter spesialis dengan biaya yang lumayan besar.

Ibu yang bekerja diharapkan dapat berperan dalam meningkatkan keadaan sosial ekonomi keluarga, dimana dengan tingkat sosial ekonomi yang baik maka keluarga mampu mengkonsumsi makanan yang bergizi. Namun masih sangat banyak ibu hamil yang melakukan pemeriksaan di Rumah Sakit Umum Daerah dr.Zainoel Abidin tidak bekerja. Hal ini dapat disebabkan dari tingkat pendidikan responden tersebut. Ibu hamil yang tidak bekerja dan mengalami anemia dapat diasumsikan karena tidak terpenuhinya asupan zat besi yang baik bagi tubuh ibu dan kurangnya pendidikan dan pengetahuan ibu hamil dalam pemenuhan kebutuhan zat gizi selama hamil. 
6. Hubungan Asal Rujukan dengan Kejadian Anemia

Dari hasil penelitian terlihat bahwa ibu hamil dari kelompok kasus yang dirujuk dari puskesmas sebanyak 155 responden dan dari rumah sakit 18 responden. Sedangkan dari kelompok kontrol ibu hamil dirujuk dari puskesmas sebanyak 330 responden dan dari rumah sakit 16 responden. Dapat disimpulkan bahwa ibu hamil yang melakukan pemeriksaan di Rumah Sakit Umum Daerah dr.Zainoel Abidin asal rujukan dari puskesmas. Hal ini dikarenakan ibu hamil tersebut melakukan pemeriksaan di poli kebidanan dan ini merupakan pasien rawat jalan yang semua berasal dari puskesmas Aceh Besar dan Banda Aceh Namun ada beberapa orang ibu hamil yang mengalami anemia dilakukan rawat inap dikarenakan mengalami komplikasi tambahan. Dan ada pula ibu hamil yang mengalami anemia namun dirujuk dari rumah sakit, hal ini dikarenakan ibu hamil tersebut mengalami anemia berat disertai komlikasi penyakit lainnya yang tidak bisa ditangani lagi oleh rumah sakit tempat asal rujukan tersebut.

7. Hubungan Layanan Kesehatan dengan Kejadian Anemia

Hasil penelitian di atas terlihat bahwa tidak ada hubungan antara layanan kesehatan dengan kejadian anemia ibu hamil yang melakukan pemeriksaan di Rumah Sakit Umum Daerah dr.Zainoel Abidin Provinsi Aceh. Hal ini dikarenakan keterbatasan peneliti yang hanya melihat dari rasio bidan dengan jumlah wanita usia subur yang ada di wilayah kerja puskesmas tempat asal rujukan pasien. Jumlah bidan di Provinsi Aceh sudah melebihi standar yang ditetapkan WHO, seperti yang terlihat dari profil Dinas Kesehatan Provinsi Aceh, jumlah bidan tahun 2013 sebanyak 10.660 orang, dengan rasio 445 per 100.000 penduduk. Sedangkan tahun 2015 jumlah bidan tercatat sebanyak 10.371 orang, dengan rasio 211,4 bidan per 100.000 penduduk. Dilihat dari rasio bidan dengan jumlah penduduk tersebut melebihi target nasional dan standar WHO sebesar 100 per 100.000 penduduk.

Ibu hamil berisiko mengalami anemia bukan hanya dikarenakan layanan kesehatan yang ia dapatkan saja, namun banyak faktor pendukung lainnya seperti asupan zat besi, kepatuhan mengkonsumsi tablet zat besi, pengetahuan dan lain-lain. 


\section{KESIMPULAN}

Berdasarkan hasil penelitian dapat disimpulkan bahwa ada hubungan umur $(\mathrm{p}=$, paritas $(\mathrm{p}=$, umur kehamilan $(\mathrm{p}=$, pendidikan $(\mathrm{p}=$, pekerjaan ( $\mathrm{p}$ dan asal rujukan $(\mathrm{p}=$ dengan kejadian anemia ibu hamil, sedangkan layanan kesehatan tidak berhubungan dengan kejadian anemia ibu hamil dengan $p$ value $=0,299(>0,05)$.

\section{SARAN}

Setiap ibu hamil berisiko mengalami anemia, sebaiknya para petugas kesehatan dapat memberikan penyuluhan kesehatan pada ibu hamil mengenai kebutuhan zat gizi selama kehamilan dan faktor-faktor lain yang dapat memicu terjadinya anemia selama kehamilan. Pada umur ibu ( $<20$ tahun dan $>35$ tahun) berisiko mengalami anemia selama kehamilan sehingga para petugas kesehatan dapat memberikan informasi kepada para wanita usia muda untuk memunda pernikahan usia dini dan pada wanita usia lanjut sebaiknya mencukupkan kehamilannya agar tidak terjadi komplikasi pada saat kehamilan dan persalinan salah satunya mengalami anemia. Namun apabila sudah hamil dalam usia berisiko ini, maka sebaiknya ibuibu rutin melakukan pemeriksaan kondisi ibu dan janin selama kehamilan. Petugas kesehatan dapat memberikan penyuluhan kesehatan kepada ibu hamil tentang anemia selama kehamilan, hal ini dikarenakan pada saat hamil kebutuhan zat besi meningkat, untuk itu disarankan kepada ibu hamil agar mengonsumsi makanan dengan zat gizi baik serta mengonsumsi suplemen zat besi (tablet Fe) selama kehamilan secara rutin dan tetap mengontrol kondisi kesehatan ibu dan janin dengan melakukan pemeriksaan antenatal care. Bagi peneliti selanjutnya untuk dapat melakukan penelitian lanjutan mengenai anemia pada ibu hamil namun dengan variabel yang berbeda seperti variabel jarak kehamilan, sosial ekonomi, budaya, pengetahuan, media informasi dan lain-lain.

\section{UCAPAN TERIMA KASIH}

Ucapan terima kasih kepada Universitas Ubudiyah Indonesia yang telah memberikan dukungan finansial dalam penelitian ini dan ucapan terima kasih kepada Direktur Rumah Sakit Umum Daerah dr. Zainoel Abidin Provinsi Aceh yang telah memberikan izin penelitian. 


\section{DAFTAR PUSTAKA}

[1] Proverawati dan Asfuah. 2009. Buku Ajar Gizi untuk Kebidanan. Yogyakarta : Muha Medika.

[2] Manuaba. 2010. Ilmu Kebidanan Penyakit Kandungan dan KB. Jakarta : EGC

[3] Riset Kesehatan Dasar. 2013. Riskesdas 2013. Badan Penelitian dan Pengembanganan Kesehatan. Kementrian Kesehatan RI:2013.

[4] Rumah Sakit Umum Daerah dr. Zainoel Abidin Provinsi Aceh.

[5] World Health Organization (WHO). 2008. Diunduh dari www.who.org. Diakses tanggal 4 November 2015.

[6] Gedefaw, Ayele, Asres dan Mossie. 2014. Anemia and associated factors among pregnant Women attending antenatal care clinic in Wolayita sodo town, southern Ethiopia. Vol. 25, No.2. Diunduh dari :http://www.researchgate.net/ pub lication /279629181. Diakses tanggal 4 November 2015.

[7] Luthfiyati, Yana. 2012. Faktor-faktor yang Berhubungan dengan Kejadian Anemia pada Ibu Hamil di Puskesmas Jetis Kota Yogyakarta Tahun 2012. Vol.X Nomor 2. ISSN : 1907-3887. Jurnal Medika Respati.

[8] Nwachi, Odekunle, Jacinto, Burnett, Clapperton, David, Durga, Greene, Jarvis, Nixon, Seerereram, Poon-king dan Singh. 2010. Anemia in Pregnancy : Associations With Parity, Abortions and Child Spacing in Primary Healthcare Clinic Attendees in Trinidad and Tobago. Diunduh dari : http://www.ncbi.nlm.nih.gov. Diakses tanggal 4 November 2015.

[9] Zama, Isaac, et al. 2014. Socio-demographic and obstetric factors associated with anaemia among pregnant women in Sokoto, North Western Nigeria. ISSN: 2375-379X. Diunduh dari http://www.aascit.org/journal/hsr. Diakses tanggal 4 November 2015.

[10] Mokhtar dan Soadaan. 2012. Prevalence and Risk Factors of Anemia among a Sample of Pregnant Females Attending Primary Health Care Centers in Makkah, Saudi Arabia. Pakistan Journal of Nutrition 11(12):1113-1120 · December 2012

[11] Norfai. 2015. Konsumsi Tablet Besi (Fe) Sebagai Determinan Kejadian Anemia pada Ibu Hamil di Wilayah Kerja Puskesmas Alalak Tengah Kota Banjarmasin Tahun 2015. Jurnal-Tesis. Program Studi Ilmu Kesehatan Masyarakat. Urindo. Jakarta Timur.

[12] Islamiyati. 2005. Faktor-faktor yang berhubungan dengan Kejadian Anemia Ibu Hamil di Povinsi Lampung. Tesis. Program Pasca Sarjana Kesehatan Masyarakat, FKM UI, Depok.

[13] Suarsih, Acih. 2012. Determinan Kejadian Anemia pada Ibu Hamil Trimester I dan III dan Faktor Risikonya di Wilayah Kerja Puskesmas Cikupa Kabupaten Tanggerang (Tesis). Jakarta : Universitas Respati Indonesia.

[14] Zebua. 2011. Faktor-faktor yang berhubungan dengan kejadian anemia gizi pada ibu hamil di wilayah kerja puskesmas tuhemberua kabupaten nias utara. http://repository.usu.ac.id. 
Journal of Healthcare Technology and Medicine Vol. 3 No. 1 April 2017

Universitas Ubudiyah Indonesia

e-ISSN : 2615-109X

[15] Melisa. Fitri dan Djauhari. 2013. Faktor Risiko yang Berhubungan dengan Kejadian Anemia pada Ibu Hamil. Diunduh dari : online-journal.unja.ac.id. Diakses tanggal 4 November 2015. 